\title{
Translation of Transylvanian Culture-Specific Items into English
}

\author{
Árpád KÉMENES \\ Sapientia Hungarian University of Transylvania (Miercurea Ciuc, Romania) \\ Department of Humanities \\ kemenesa@yahoo.com
}

\begin{abstract}
The present paper focuses on some difficulties encountered during the translation of culture-specific items in Zsuzsa Tapodi's articles Links between the East and the West: Historical Bonds between the Hungarians and the Balkan Peoples and Hungarian Ethnographic Region in Romania, published in the May 2014 issue of Carmina Balcanica. As far as the theoretical framework adopted in this study is concerned, the terminology on translation strategies relies on the taxonomy developed by Aixelá (1996), while the classification of culture-specific items has been influenced by Dimitriu (2002) and Yılmaz-Gümüş (2012). The study provides a definition of the term 'culture-specific item', considers the targetreaders' awareness of source-language culture, and presents a number of translation strategies applied to mediate culture-bound information between the source and target cultures.
\end{abstract}

Keywords: lingua franca, target reader, source culture awareness, intratextual gloss, extratextual gloss, intertextual corpus

\section{Introduction}

Recent technological achievements facilitating people's access to information, the development of electronic media as well as the modernisation of transportation have led to an unprecedented increase in cultural interactions (Hidasi 1997), as a consequence of which there is growing need for producing and translating texts that contain culture-bound information.

The present paper focuses on some difficulties encountered during the translation of culture-specific items in Zsuzsa Tapodi's studies Links between the East and the West: Historical Bonds between the Hungarians and the Balkan Peoples (Tapodi 2014a) and Hungarian Ethnographic Regions in Romania (Tapodi 2014b) published in Carmina Balcanica. As far as the theoretical framework adopted in this paper is concerned, the terminology on translation strategies relies on the taxonomy 
developed by Aixelá (1996), while the classification of culture-specific items has been influenced by Dimitriu (2002) and Yılmaz-Gümüş (2012).

The sections that follow provide a definition of the term 'culture-specific item', consider the target-readers' awareness of source-language culture, and present a number of translation strategies applied to mediate culture-bound information between the source and target cultures.

\section{The definition of the term 'culture-specific item'}

Mediation of culture-bound information is a major challenge for translators. Researchers involved in translation theory have coined different terms to refer to these 'untranslatable' items, such as 'lexis without equivalence', 'realia' or 'culture-specific items', all referring to "names of objects typically characteristic of a particular language community (meals, clothes, dishes, dances, etc)" that "cannot be translated into the language of a community which does not know it" (Klaudy 2003: 40, 41).

Aixelá (1996: 58) broadens the scope of the concept. He defines it as including "those textually actualized items whose function and connotations in a source text involve a translation problem in their transference to a target text, whenever this problem is a product of the nonexistence of the referred item or of its different intertextual status in the cultural system of the readers of the target text." According to the definition above, the term 'culture-specific item' also refers to lexical items that exist both in the target and the source cultures but with different connotations.

\section{The target readers}

Written originally in Hungarian, the articles analysed have been translated into English and Romanian. The two versions address different target readers, which results in a number of discrepancies between the texts.

Obviously, the English version targets the native speakers of the language, so the translator had to anticipate the degree of source-culture awareness of societies living in English speaking countries. However, owing to its status as a lingua franca, English "gradually loses track of its cultural identity - its idioms, its hidden connotations, its grammatical subtleties - and turns into a bland and flattened 'plastic language' or 'langue de plastique' available for the common denominator of international communication" (Snell-Hornby 1997: 29). Thus, part of the prospective readers may share neither the culture of the source language, nor that of the target language. 
The heterogeneity of the target readers' background knowledge about Romania in general and Transylvania in particular leads to the hypothesis that however detailed the intratextual and extratextual glosses inserted by the translator, the culture-bound information included in the translated texts remains underspecified for a great number of readers. Therefore, when looking for English equivalents of culture-specific items, the translator must always be guided by the idea that the word or phrase chosen should facilitate readers in carrying out quick individual research into the topic. That is to say, the "support of pre-established translations within the intertextual corpus of the target language” (Aixelá 1996: 61) is of utter importance. As the most efficient way of obtaining information is looking for key-words on the internet, in the majority of cases the equivalent chosen during the translation of the articles was the one that gave access to accurate and comprehensive information when typed into web search engines.

The sections that follow expound on further guidelines and strategies concerning the translation of culture-specific items.

\section{Reference to geographical names}

Toponyms are regarded as typical examples for conservation and unaltered repetition of items when they are transferred from the source language into the target language. However, in Transylvania, where three parallel toponymic layers coexist, decision has to be made on whether the Romanian, Hungarian or the German variant should be adopted in the English translation. Usually the choice does not depend on the translator. Supratextual criteria such as the writer's aim or the publisher's policy are taken into consideration. In our particular case, when translating geographical names, two factors had to be considered: firstly, the author's and the publisher's common aim to familiarize the readers with the culture of the Hungarians inhabiting the Carpathian Basin - with special emphasis on the Hungarian community living in present-day Romania, and secondly, the principle mentioned in the previous section of this study, namely to ensure the possibility for readers to obtain further information on the culture-specific terms via internet or other sources available in English.

\subsection{Human settlements}

Having in view the factors mentioned above, in the case of city, town and village names it was the Romanian toponym that appeared in the body of the text, while, where necessary, the Hungarian equivalent was inserted in brackets, as extratextual gloss. In order to help readers find the location of these places, the 
English variant is much more consistent in providing information on the counties these localities are situated in than the Hungarian and Romanian variants.

\subsection{Ethnographic regions}

When translating region names, the major difficulty encountered was the lack of widely used and accepted English equivalents. The relatively few native English authors who have written about different regions of Romania had to elaborate their own strategies for altering the Hungarian, the Romanian or the German toponyms in a way these geographical names can seamlessly fit into the English context. These 'personal solutions' have resulted in several English alternatives denoting the same geographic or ethnographic area. Translations of region names such as Székelyföld, Kalotaszeg or Mezöség provide examples on attempts to solve this problem.

The ethnographic area known by the Hungarians as Székelyföld is most often referred to in English as the Székely Land (Reid 2007; Mallows 2008; Howard 1996) or - basing on the German toponym - as the Szeklerland (Minahan 2002; Turnock 2013; Smith \& Richards 2013). Other writers use the following terms: Székely region (Hupchick 1995; Hooker 2013), Szekler region (McMahon 2007; Parish \& Naphy 2002), Székely district (Frucht 2005; Eby 2007), Szekler district (Frucht 2005), Székely area (Neilson 2004), Szekler area (Reisser 2012), land of the Székelys (Cornish 1947) or land of the Szeklers (Fermor 2010). Of the variants that appear more frequently in the intertextual corpus, the term Szeklerland was chosen in the translation of the two analysed studies.

The ethnographic region Kalotaszeg seems more problematic to be rendered in an English context. Native English writers rarely, if ever, refer to this region by its Romanian name, Țara Călatei. On 23 March 2014 the website www.books. google.co.uk found no results for English books containing the term 'Tara Calatei'. Sometimes the name Kalotaszeg is used without any glosses in the English text (MacWhinney 2010), but the general tendency is to insert intratextual glosses such as Kalotaszeg area (Howard 1996), Kalotaszeg region (Mallows 2008), or the district of Kalotaszeg (Mann 1968). In English texts not written by Romanian authors, we found only one variant, with intratextual gloss, stemming from the Romanian toponym: Călata district (Schöpflin \& Poulton 1990). However, references have been found where the Romanian and Hungarian names of the region appear together, one being the extratextual gloss for the other, like in the following examples: Kalotaszeg (now Călata) region (White 2000) or the area of Călata (Kalota), Transylvania, Romania (Szabó T. 2009). Reid (2007) uses the term Huedin Microregion (Kalotaszeg), making reference to the urban centre of the area. In Tapodi (2014b) the term Călata District is used, followed by the region's Hungarian name in brackets as extratextual gloss. Although the term chosen is not 
the most frequent one in the intertextual corpus, it contributes to the consistency of the article as far as the use of the Romanian and Hungarian toponyms is concerned. Moreover, knowing that Kalotaszeg has never been an administrative entity of its own, by choosing the noun district instead of region, the translator makes distinction between the ethnographic area and the administrative unit that existed in Romania between 1950 and 1968 (see section 4.3.).

Mezôség is both an ethnographic and a physical-geographical region of Transylvania. Having no established translation into English, in this case, too, different sources provide different terms to refer to the region. Some Hungarian authors conserve the Hungarian name of the area, coining English variants like the Transylvanian Mezôség (Pozsony 2006) or the Mezôség of Transylvania (Balassa \& Ortutay 1984). Broughton (1994) refers to the region as the Transylvanian "Heath", which is in fact the loan-translation of the German toponym Siebenbürgische Heide.

The most often used English variant, Transylvanian Plain (e.g. Mallows 2008), is an erroneous loan-translation of the Romanian Câmpia Transilvaniei. The source of the mistranslation is the polysemy of the Romanian word câmpie.

Consulting the Dicționar explicativ al limbii române (1998), one of the most representative Romanian monolingual dictionaries, one can notice partial synonymy between the words câmp ${ }^{1}$ and câmpie. ${ }^{2}$ The two entries are provided below:

CÂMP, câmpuri, s.n. şi (1, astăzi mai ales în expr.) câmpi, s.m. 1. Întindere vastă de pământ fără accidente însemnate de teren ${ }^{3}$; şes ${ }^{4}$, câmpie ${ }^{2}$; spec. Întindere de pământ cultivată, semănată; totalitatea ogoarelor din jurul unei comune ${ }^{5}$. [...]

CÂMPÍE, câmpii. s.f. Întindere vastă de pământ fără accidente însemnate de teren ${ }^{3}$; şes ${ }^{4}$, câmp ${ }^{1}$ - câmp + suf.-ie.

The translation Transylvanian Plain is based on the sense of the word câmpie coinciding with the first sense of the word câmp (both in Levițchi's RomanianEnglish Dictionary - see footnotes 1 and 2 - and in the Dicționar explicativ al limbii române): that of the expansion of land with no significant elevation changes. However, the Cîmpia Transilvaniei entry of the Romanian Encyclopedic Dictionary (Dicționar Enciclopedic), volume 1 (1993: 399), provides the following information:

1 cîmp I. s.n. 1. field; (şes) plain, level (country). 2. agr. field. 3. (fond) ground. 4. (margine) margin. 5. fig. field; sphere; domain; range, scope. (Levițchi 2003)

2 cîmpie s.f. plain, level (country); (țară de jos) lowland. (Levițchi 2003)

3 Huge expansion of land with no significant elevation changes. [Translated by the author.]

$4 \quad$ şes I. adj. flat, plain. II. s.n. plain. (Levițchi 2003)

5 spec. Expansion of cultivated, cropped land; the totality of fields surrounding a village. [Translated by the author.] 
The vernacular denomination, with the element "cîmpie", only refers to its ancient agricultural function, because neither the land relief nor the majority of its other landscape components justify the inclusion of this unit into the category of plains proper. [...] Deforested at an early age, C. T. has become an important agricultural area, with arable lands predominating in a proportion of $70-80 \%$ in the $\mathrm{S}$ and $30-40 \%$ in the $\mathrm{N}$, on which cereals, sugar-beet, sunflower etc. are cultivated. ${ }^{6}$

The quotation above leads to the conclusion that besides the definition provided by the Dicționar explicativ al limbii române and the English equivalents given in Levițchi's dictionary, in the particular case analysed in our study, the word câmpie is used in a sense referring to the agricultural function of the region. Thus, the synonymy between câmpie and câmp has to be extended over the specialised sense of the word câmp provided by the Dicționar explicativ al limbii române, as well: the expansion of cultivated, cropped land; the totality of fields surrounding a village (which coincides with sense 2 in Levițchi's dictionary - see footnote 1).

Mallows (2013) tries to capture the meaning of the Hungarian word Mezóség, i.e. the 'totality of fields' (which is actually identical with the meaning of the Romanian Câmpie presented above), by the word Fieldness. In Tapodi (2014b) the term Transylvanian Fieldland is used. Both Fieldness and Fieldland emphasize the agricultural land-use predominant in the region. Which of the two denominations sounds more natural for native English speakers, can be a topic of debate.

\subsection{Administrative units}

The administrative unit called judet in present-day Romania is consistently translated as county in travel guides (e.g. Mallows 2008, 2013; Reid 2007), a variant which is adopted in the translation of Zsuzsa Tapodi's studies, as well. It has to be mentioned, however, that references have been found where the Romanian name of the entity is conserved in the English text (Reviews of National Policies for Education: Romania 2000), and, marginally, where some authors refer to this administrative unit as district (e.g. Nurnberg 1999).

The translation of historical administrative entities of Romania is less unified. The examples provided below show different variants that appear as English translations of the administrative unit known in Romanian under the name of

6 In original: „Denumirea populară, cu atributul de 'cîmpie', se referă numai la funcționalitatea sa agricolă, străveche, fiindcă nici relieful şi nici majoritatea celorlalte componente ale peisajului nu justifică încadrarea acestei unități în categoria cîmpiilor propriu-zise. [...] Defrişată de timpuriu, C.T. a devenit o importantă zonă agricolă, terenurile arabile predominînd în proporție de 70-80\%, în S şi 30-40\% în N, pe care se cultivă cereale, sfeclă de zahăr, floarea-soarelui etc." [Translated by the author.] 
Regiunea Autonomă Maghiară (in Hungarian: Magyar Autonóm Tartomány), which existed between 1952 and 1960.

Recently published books such as White (2000) and Minahan (2002) use the denomination Magyar Autonomous Region. The historian Stefano Bottoni, who has published writings about this region, refers to it as the Hungarian Autonomous Region (Bottoni 2003), while other authors call this historic subdivision of the country the Hungarian autonomous district (Crampton 2002) or the Hungarian Autonomous Province (McMahon 2007). The term adopted in the translation of the texts analysed is Magyar Autonomous Region, because this is the denomination that figures on English maps published in the sixth decade of the $20^{\text {th }}$ century (e.g. Bartholomew 1956), so it can be hypothesized that it was this form of the term that appeared in the discourse of that time period.

\section{Reference to buildings or sites with historical significance}

Although Transylvanian historical landmarks have well-established names in Hungarian and Romanian, their translation into English is less unified. In what follows, alternative translations are presented, which denote sites significant for the Hungarian culture, mentioned in Tapodi (2014a, 2014b).

Travel guidebooks are quite consistent regarding the translation of one of the most important places of interest in Târgu Mureş referred to as Kultúrpalota in Hungarian and Palatul Culturii in Romanian. Mallows (2008) names it Palace of Culture, Reid (2007) and Williams (1998) call it Culture Palace. The denomination adopted in Tapodi (2014b) is Cultural Palace.

The English reference to another building of outstanding importance situated in the same city, called Közigazgatási Palota or Megyeháza in Hungarian and: Palatul Prefecturii in Romanian, is less unified. Reid (2007) calls it County Council Building, Williams (1998) names it Prefecture, while Mallows (2008: 179) describes it as the "Old Town Hall (1907), which is now government offices [...]." In Tapodi (2014b) the term the residence of the Mureş County Council is used.

The most famous cemetery in Cluj-Napoca named Házsongárdi temetó in Hungarian and Cimitirul Central [Central Cemetery] in Romanian, also appears under different denominations in English texts written by native English authors. Some of them conserve its Hungarian name. For example, Mallows (2008) calls it Házsongárdi Cemetery, while Reid (2007: 190) refers to it as an "immense, highly memorable Hungarian cemetery (Map p186; Házsongárdi temetó in Hungarian), where dozens of revered Hungarian notables are buried.” Le Bas \& Bell (2007) name it the Hajongard Cemetery, while Brubaker (2006), based on the Romanian denomination of the landmark, refers to it as the Central Cemetery. Owing to the 
discrepancy between the Hungarian and the Romanian names of the site, when first mentioned, both the term Házsongárd Cemetery and that of Central Cemetery are present in Tapodi (2014b), one being the extratextual gloss of the other. Later in the text the site is referred to only as Házsongárd Cemetery, reiterating thus its importance in the Hungarian culture. The adjective-forming derivational suffix $-i$ denoting 'belonging to' or 'pertaining to' has been deliberately removed from the name used in the English translation.

Two sites with particular importance for the Hungarian culture situated in the southern part of Transylvania - mentioned in Zsuzsa Tapodi's studies - are analysed in this paper. The first one is called Déva vára in Hungarian and Cetetea Devei or Cetatea Deva in Romanian. English guidebooks often refer to it as the Citadel (Williams 1998, Reid 2007), Deva Castle (Mallows 2008), Deva Fortress (Rennon 2007). Leader (1967) names it castle of Déva, while in Tapodi (2014b) the denomination fort of Déva appears, following Brewster (1996).

The second landmark is Vajdahunyad vára in Hungarian. Texts in Romanian refer to it as Castelul Corvineştilor, Castelul Corvinilor, Castelul Hunedoarei or Castelul Huniazilor. English guidebook writers term it as Hunedoara Castle (Williams 1998), referring to the Romanian name of the town where it is situated, or Corvin Castle (Mallows 2008, Reid 2007), identifying the building by its first owners: the Hunyadi family (the Latin word 'corvinus' means 'raven' in English - a bird depicted on the coat of arms of the Hunyadi family). In English texts the denomination Vajdahunyad Castle (the first component of which is the Hungarian name of the town Hunedoara) refers to the replica of the edifice built in Budapest for the 1896 Millennial Exhibition (e.g. Smyth 2012). However, the name Hunyad Castle, based on the shortened Hungarian name of the town, can often be encountered in the English intertextual corpus (e.g. Weil 2012). In Tapodi (2014a), the translator chose the variant Corvin Castle mostly because this denomination is biased towards neither the Hungarian nor the Romanian culture. Thus, the term fits the context of the paragraph where it appears, which describes John Hunyadi as a person of high esteem, revered as a hero by the Hungarians, Romanians and the South Slavic people, as well.

\section{Conclusions}

Translation of culturally loaded texts cannot be successful without taking into consideration the source-culture awareness of the target readers - a task particularly difficult to accomplish when these writings are to be conveyed into English. Owing to the status of English as a lingua franca, texts written in English address not only native speakers, but also readers belonging to a wide range of cultures. Therefore, when trying to find target-language equivalents 
of culture specific items, the translator is advised to choose pre-established terms or denominations that are easily accessible for prospective readers in the English intertextual corpus, helping them obtain additional information on the topic. Another principle that the translator should never overlook is consistency throughout the translation.

In the translations of Zsuzsa Tapodi's studies, intratextual and extratextual glosses are used to facilitate the readers' understanding of the culturally loaded information the texts intend to convey. The main difficulty consisted in deciding whether to rely on the Hungarian, the Romanian or the German variants when conveying a term into English. Whenever linguistic translation was not possible or appropriate, basing on the principle of accessibility, one of the pre-established variants included in the intertextual corpus was chosen, while when the repetition of a toponym was required, it was the Romanian version that appeared in the body of the text, followed by the Hungarian denomination as an extratextual gloss.

\section{References}

Aixelá, Javier Franco. 1996. Culture-Specific Items in Translation. In Álvarez, Roman \& M. Carmen-África Vidal (eds.), Translation, Power, Subversion, 5278. Clevedon: Multilingual Matters.

Balassa, Iván \& Gyula Ortutay. 1984. Hungarian Ethnography and Folklore. Corvina Kiadó.

Bartholomew, John (ed.). 1956. The Times Atlas of the World. Vol. IV: Southern Europe and Africa. Boston: Houghton Mifflin Company.

Bottoni, Stefano. 2003. The creation of the Hungarian Autonomous Region in Romania. Regio (English issue): 15-38.

Brewster, Paul G. 1996. The Foundation Sacrifice Motif in Legend, Folksong, Game and Dance. In Dundes, Alan (ed.), The Walled-Up Wife, 35-62. Madison: The University of Wisconsin Press.

Broughton, Simon. 1994. Rough Guide to World Music. London: Dorling Kindersley Ltd.

Brubaker, Rogers (ed.). 2006. Nationalist Politics and Everyday Ethnicity in a Transylvanian Town. Princeton University Press.

Cornish, Louis Craig. 1947. Transylvania: The Land Beyond the Forest. Dorrance \& Company.

Crampton, Richard J. 2002. Eastern Europe in the Twentieth Century - and After. Routledge.

Dimitriu, Rodica. 2002. Theories and Practice of Translation. Iaşi: Institutul European. 
Eby, Cecil D. 2007. Hungary at War: Civilians and Soldiers in World War II. Pennsylvania State University Press.

Fermor, Patrick Leigh. 2010. Words of Mercury. Hachette UK Company.

Frucht, Richard (ed.). 2005. Eastern Europe. An Introduction to the People, Lands and Culture. Santa Barbara: ABC-CLIO Inc.

Hidasi, Judit. 1997. Crosscultural Differences in Users' Expectations. In Klaudy, Kinga - János Kohn (eds.), Transferre Necesse Est, 97-101. Budapest: Scholastica.

Hooker, Lynn M. 2013. Redefining Hungarian Music from Liszt to Bartók. Oxford University Press.

Howard, Jeremy. 1996. Art Nouveau: International and National Styles in Europe. Manchester University Press.

Hupchick, Dennis P. 1995. Conflict and Chaos in Eastern Europe. Palgrave Macmillan.

Klaudy, Kinga. 2003. Languages in Translation. Budapest: Scholastica.

Leader, Ninon. 1967. Hungarian Classical Ballads and their Folklore. Cambridge University Press.

Le Bas, Tom \& Brian Bell. 2007. Insight Guides: Romania. APA Publications.

Levițchi, Leon. 2003. Romanian-English Dictionary. Bucureşti: Editura 100+1 Gramar.

MacWhinney, Brian. 2010. Language Development. In Overton, Willis F. \& Richard M. Lerner (eds.), The Handbook of Life-Span Development. Vol. 1. Hoboken, New Jersey: John Wiley \& Sons Inc.

Mallows, Lucy. 2008. Transylvania. Bradt Travel Guides.

Mallows, Lucy. 2013. Transylvania (2 ${ }^{\text {nd }}$ edition). Bradt Travel Guides.

Mann, Kathleen. 1968. Peasant Costume in Europe. London: Adam and Charles Black.

McMahon, Patrice C. 2007. Taming Ethnic Hatred: Ethnic Cooperation and Transnational Networks in Eastern Europe. Syracuse University Press.

Minahan, James. 2002. Encyclopedia of Stateless Nations. Vol. IV S-Z. Greenwood Publishing Group.

Neilson, Brett. 2004. Free Trade in the Bermuda Triangle - and Other Tales of Counterglobalization. University of Minnesota Press.

Nurnberg, Barbara. 1999. The State after Communism: Administrative Transitions in Central and Eastern Europe. Washington D.C.: The World Bank.

Parish, Helen \& William G. Naphy. 2002. Religion and Superstition in Reformation Europe. Manchester University Press.

Pozsony, Ferenc. 2006. The Hungarian Csángó of Moldova. Corvinus Publishing. Reid, Robert. 2007. Romania and Moldova. Lonely Planet Publications.

Reisser, Wesley J. 2012. The Black Book. Woodrow Wilson's Secret Plan for Peace. Lexington Books. 
Rennon, Rosemary. 2007. Language and Travel Guide to Romania. New York: Hippocrene Books.

Schöpflin, George \& Hugh Poulton. 1990. Romania's Ethnic Hungarians. Minority Rights Group.

Smith, Melanie \& Greg Richards. 2013. Routledge Handbook of Cultural Tourism. Routledge.

Smyth, Robert. 2012. Frommer's Budapest Day by Day. Chichester: John Wiley and Sons Inc.

Snell-Hornby, Mary. 1997. Lingua Franca and Cultural Identity - Translation in the Global Village. In Klaudy, Kinga - János Kohn (eds.), Transferre Necesse Est, 27-36. Budapest: Scholastica.

Szabó T., Attila. 2009. Phaselous as a model taxon for monitoring trends in European home garden diversity: a methodological approach and proposal. In Bailey, Arwen \& Pablo Eyzaguirre \& Lorenzo Maggioni (eds.), Crop genetic resources in European home gardens, 37-54. Maccarese: Biodiversity International.

Tapodi, Zsuzsa. 2014a. Links between the East and the West: Historical Bonds between the Hungarians and the Balkan peoples. Carmina Balcanica, vol. VI, no. 1(12): 82-92.

Tapodi, Zsuzsa. 2014b. Hungarian Ethnographic Regions in Romania. Carmina Balcanica, vol. VI, no. 1(12): 104-115.

Turnock, David. 2013. Aspects of Independent Romania's Economic History with Particular Reference to Transition for EU Accession. Ashgate Publishing Ltd. Weil, Ann. 2012. The World's Most Amazing Castles. London: Capstone Global Library Limited.

White, George W. 2000. Nationalism and Territory: Constructing Group Identity in Southeastern Europe. Lanham: Rowman \& Littlefield Publishers Inc. Williams, Nicola. 1998. Romania \& Moldova. Lonely Planet Publications. Yllmaz-Gümüss, Volga. 2012. Translation of Culture-Specific Items in Self-Help Literature: A Study on Domestication and Foreignization Strategies. English Language Overseas Perspectives and Enquiries 9 (Autumn): 117-129.

*** 1993. Dicționar Enciclopedic. Vol. I A-C. [Encylopedic Dictionary, vol. I A-C.] Bucureşti: Editura Enciclopedică.

*** 1998. Dicționar explicativ al limbii române. [Romanian Explanatory Dictionary.] Bucureşti: Editura Univers Enciclopedic. *** 2000. Reviews of National Policies for Education: Romania. OECD Publishing. 